\title{
Public Service and Democracy in Developing Societies: The Nigerian Experience
}

\author{
Bonnie Ayodele and Kehinde Bolaji* \\ Department of Political Science, University of Ado Ekiti, Nigeria \\ Telephone: 234-8038475573, 234-8028301895, E-mail: bonnieayodele@yahoo.com \\ *Public Policy Analyst, Julius and Julius Associates, Ibadan, Oyo State, Nigeria
}

KEYWORDS Public service; democracy; developing societies; efficiency

\begin{abstract}
The public service remains very critical and crucial to national development and democratic stability in developing societies. While years of military rule and authoritarian regimes in most developing societies have impacted negative political culture on the character and philosophy of the service, yet, its roles in national development cannot be undervalued. However, since military regimes and other authoritarian regimes have lost their appeal in modern government the need to reform public service to be in tune with democratic values becomes highly imperative. There is no gainsaying that the public service plays critical role in galvanising the nation and its resources to development. An efficient public service acts as catalyst in the development of nations. While on the other hand, its inefficiency can constitute as one of the heaviest millstones round the neck of developing nations. Therefore, it is important to note that the public service must be efficient to service the newly found democratic project for stability and survival of the polity. Since it is the vehicle and machinery of public policy formulation and implementation, the service has a very critical role to play. It is also worthy to note that democracy with its attractive valves will enhance the workings of the public service and redefine, re-orientate and reposition it to be more effective, mobile and productive partner in national reconstruction agenda. Public service must be a partner in reform driving which is imperative for democratic survival. This paper therefore intends to examine the symbolic and complementary roles of public service and democracy in developing societies especially a transiting society from authoritarian rule to democracy.
\end{abstract}

\section{INTRODUCTION}

In developing societies, the challenges of development and stability of the polity depends on a great deal on the efficient, effective, mobile, accountable public service system and the robustness of its democratic system. There is no contention that democratic governance remains the most attractive option in the provision of social services, ensuring fairness and accountability, it also creates impetus for national development. That is democracy with its values system can engineer meaningful development to human society. In achieving this, the public service must provide the machinery and acts as a springboard for such development, stability and consolidation of democratic dividends. Therefore, the relationship between the public service system and democracy must be symbiotic as well as complementary for the overall survival of the polity. In fact, public service contribution is crucial to the very survival, consolidation, stability and development of democracy as well as the society in general. The collaborative roles of the public service in governance, policy formulation and implementation rest largely on the institutional machinery of government like the civil service, defense forces, diplomatic service, the legislature, regulative commissions etc. These institutions are set up to ensure the smooth working of the various components that make up the state. There is no gainsaying the fact, that the future growth and development of a nation depends on the strength and ability of the public service to develop a science and a philosophy of administration competent to discharge social goods in the developing societies (Stone, 1986: 2). In functional terms, public service involves the process of rule application, that is, the process through which general social rules are converted into specific observable decisions to better the lives of the people (Agagu, 1997: 233).

\section{CONCEPTUALISING PUBLIC SERVICE AND DEMOCRACY}

The strategic relevance of public service in policy formulation and implementing cannot be over emphasised. In the developing societies especially in the immediate post independence era the public service assumed the pivotal roles as the vehicle of development. In fact, Ejifor (2003) 
posits that public service in the developing societies is everything and that the most important catalyst of development is an efficient service while at the same time its inefficient constitute the heaviest millstones of any nation. This is similar to the view of Agagu (1997: 233) who contends that public service is the continuously active business part of government, concerned with carrying out the law, as made by the legislative bodies in the process of organisation and management. In scope, the influence of the public service is not debatable, it remains definitely a major force in today's governance. The public service contains a network of human relationships and associations extending from the highly influential government officials to the lowest paid and powerless individual charged with all resources, natural and human, and all other aspects of the life of the society with which the government is concerned (Nnoli, 2000: 44). In essence, public service is the totality of how progress and development are made in the society.

The Nigerian public service has faced a number of challenges, which has considerably undermined its capacity to serve as agent of democratic consolidation. Such challenges include those of achieving technical competence, coping with public expectation and change, behaving ethically and maintaining constitutional order (Ayo, 1998: 73). The truth is that all these problems are inextricably linked to failure of the public service to play its rightful role in system maintenance and continuity. To a large extent, the poor performance of public service in Nigeria in the areas of transparency and accountability is due largely to the quality of personnel and the authoritarian regimes. More importantly, public servants are not trained to view their service delivery as sacred and sacrosanct, while very negligible percentage of their population can recognise the impacts of their policies on the people.

However, public servants can indeed be cultivated to act as agents of democratic consolidation in Nigeria. Mimiko painstakingly listed seven elements of democratic consolidation, which needs to be reproduced. They are; challenge to non-democratic sources of power, regime change through the electoral process, mass participation in democratic process, resilience, ability of the democratic system to cope with stress defined as economic recession, ability to manage horizontal and vertical separation of power and the bureaucratic autonomy from the party in power (Mimiko, 1999: 284).

Democracy is a very wide concept on which scholars have tried, albeit in vain, to reach consensus. However, some selected definitions bear semblance to the subject of one's discussion here. Democracy connotes a system of government that meets three essential conditions viz: meaningful and extensive competition among individuals and groups (especially political parties) for all effective positions of government power at regular intervals and excluding the use of force; a highly inclusive level of political participation in the selection of leaders and policies at least through regular and fair election, such that no major group is excluded; and a level of civil and political liberties like freedom of the press, freedom to form and join organisations sufficient to ensure integrity of political competition and participation (Diamond et al., 1988: 8). Furthermore, there are five basic elements without which no community can call itself democratic. These elements are equality, sovereignty of the people, respect for human life, the rule of law and liberty of the individual (Enemuo, 1999: 44). However, all the aforementioned represent the ideals of democracy, which can be imbibed and solidified by a resolute people within a relatively long period of time. In this connection, the view expressed by Ake (cited in Ayodele, 2004: 97) that the desirability of democracy lies not in the concept itself, but that at least none of the major problems of Africa (Nigeria) can be solved without it becomes apt. Democracy must not only be nurtured in such a way that it will act as bulwark of security to the people by promoting economic growth and ushering in the desired development, which can in turn guarantee peace and security, it must also recognise people as the real indices and whose political, social and economic prosperity should be guaranteed. This can only be with the effort and sense of mission by the bureaucrats saddled with the responsibility of ensuring the formulation and implementation of policies.

The roles of the bureaucrats include challenging anti-democratic forces through policies. They should also place qualitative policies before satisfying political office holders while dedication and expertise should be exhibited in their approach towards implementation of governmental business. Though reports of ineptitude, 
bureaucratic bottleneck, high levels of corruption and personalization of governmental affairs are exhibited hitherto by the public service, democracy is expected to bear on the attitude and change these negative democratic attitude to service. Democracy has rekindled the expectation and optimism of the people in the ability of the public service to be relevant to the challenges of growth and development. The questions that logically followed are two folds, what is the antecedent of the public service in the democratisation process? and how can the public service contribute to the service of democracy to point of consolidation? In providing answers to these questions, it is imperative to critically examine the historical background of public service.

\section{HISTORICAL BACKGROUND OF THE NIGERIAN PUBLIC SERVICE}

The evolution of colonial administration in some parts of the area known as Nigeria in 1861 necessitated the establishment of structures and institutions of modern governance. Between 1900 and 1950, the Nigerian public service was dominated and controlled by British technocrats and generalist administrators. Therefore, the fact that these British officials were accountable to the authorities in Lagos rather than to the people, created an impression that they are masters rather than servants of the people they administered. Indirect rule system also contributes in no small measure to a faulty philosophy of the service. It further enhanced ethnicity, corruption and apathy. It system was equally made to serve authoritarian interests, up till the eve of independence.

During the first republic, Nigerianisation of the public service was emphasised and enhanced. Native bureaucrats cut their teeth in acrimonious, nominally democratic and deeply divided political system. This stiffed mobility of labour, responsible administration and political neutrality of the ranks and file. Even though internal bickering amongst the politicians enabled the bureaucrats to play prominent roles in policy formulation, they were not allowed to translate these policies into social realities (Adebayo, 1982). An agenda for democratic political culture was thus far from been achieved by the bureaucrats while the spirit of nationalism, patriotism, commitment, dedication and loyalty was totally absent in the service. The service was divided along ethnic contour, it makes challenges to development unattainable, stability difficult and democracy susceptible to military authoritarianism.

The period between 1966 and 1975 witnessed quite a number of radical changes in the role of Nigerian public officials. The public servants were in control of government political process due to the incursion and attraction to military rulers for politicians prevailing in the continent then, coupled with lack of experience of the political leaderships in governance. It was observed that the military governments of Generals Ironsi and Gowon relied heavily on the bureaucrats and virtually all important decisions were taken by a small group of half a dozen military leaders together with a handful of civil servant advisers (Lukman, 1971: 202-204). This turned out as a curse in disguise as the eyes of bureaucrats became open to anti-democratic ethos.

It was widely believed by the succeeding Muritala/Obasanjo regime that the public service carried its romance with the military to an extreme by engaging in graft, indolence and redundancy as to have warranted the sacking of over 10,000 of its personnel, rather than re-energise the service. The "great purge" left it demoralised, ridiculed and battered.

The democratic government of the second republic complemented the destruction with the politicisation, polarisation and fractionalisation of the service. The pre-occupation was struggle for supremacy between politicians and bureaucrats. Few people ever imagined that the public officials had some roles to play in enhancing democratic governance. Even though several reforms were put in place to re-invent the public service by successive military governments between 1983 and 1999, the reforms further clipped the wing of the service in improving the peoples' quality of life. It opened the service to the hi-tech of corrupt practices and politisation of the military. The loyalty of the service was directed to the military rulers who governed the country as an extension of a department in the defence ministry and more or less an extension of their personal estate. Suffice it to say that the reforms never addressed any of the fundamental problems confronting the public service.

The present Obasanjo democratic government ascended power with a clear-cut goal to improve the standard of living of Nigerians. It is also dedicated to the re-orientation of the public 
service to the values of diligence, honesty, well renumerated service supportive to democratic system, reforms to bring effective performance and to enable them contribute to the economic wealth of the country. Since 1999, the government has increased the salaries of workers twice, while several official hitherto deprived of promotion have been promoted (The Guardian, May 30 2004: 15). It is believed that these measures, including the organisation of training and orientation programmes, are capable of attracting/enlisting the support of the bureaucrats for democracy.

\section{PUBLIC SERVICE AND DEMOCRACY IN NIGERIA}

\section{Background to the New Policy Thrust on the Public Service in a Democracy}

Years of military authoritarianism have taken its toll on virtually all sectors of governance in Nigeria. The public service was not insulated from this mal-administration of military regimes. These years were marked by absence of debate, intimidation disregard of civil rights and nonchalance about due process and the rule of law (IDEA 2001: 43). In all, the public service was a collaborative agent in the service of authoritarianism.

The immediate post-military regime was faced with the challenges of repositioning and reforming the public service to be an active participant in the new democratic project. Thus, the question of building a democratic culture falls essentially on the crest of the public service. But first, the import of how to demilitarise an already distorted public service was crucial to the realisation of the noble roles the service is to play in the new democratic dispensation. In this light, the presidential address on the role of the civil service leadership in sustaining democratic values and implementing the national reconstruction agenda of $31^{\text {st }}$ May 1999 to the permanent secretaries in the federal civil service was rather instructive and offers an insight into the new look public service. The president made it known that the leadership of the civil service in particular has a major responsibility for ensuring that the new democratic experiment succeeds (Obasanjo 2001: 28). This he further said must be demonstrated by the attributes of courage, patriotism, foresight and precision, rectitude and loyalty to the Nigerian state and by building a consensus around core values of the service (Obansajo: ibid.).
The new dispensation makes it compelling that the trend of policy formulation and implementation must follow the norms of democratic practice, coupled with the challenges of globalisation and democratisation which must embrace evidence based decision making, and people must be at the very heart of any governmental policy. In achieving these lofty goals of good governance, which democracy presents, the civil service must undergo structural and fundamental re-orientation. The imperativeness of a public service that will be creative, information based and reform driving agents, a public service that is modern in all sense, efficient and effective is critical to the sustenance of democracy. Thus the public service must meet the challenges of the next millenium and be people oriented rather than self serving, innovative rather than rolebound, capable of forging constructive partnerships with outside groups rather than being insular (Obasanjo ibid.). It must be professionally competent and free from the malady of corruption.

- In short, the vision of the present democratic administration is to create a civil service that would be:

- a competent, professional, developmentoriented, public spirited and customer friendly public service capable of responding effectively and speedily to the need of the society; - the restoration of core values of the service such as political neutrality, impartiality, integrity, loyalty, transparency professionalism and accountability;

- a service that is guided by equity where things are done in the right way based on extant rules and regulations but with room for discretion which should be exercised in public interest; creation of a suitable environment where civil servants are assured of protection and job security in the faithful discharge of their duties and responsibilities.

- a competitive well remunerated and motivated public service (Obasanjo, 2001: 67-68)

In realising these objectives for the service, it was not surprising when the president tabled his National Economic Empowerment and Development Strategy (NEEDS) as a reform tool to transform administrative performance (Abiola, 2004: 4).

Since it was obvious that reform becomes necessary in the light of the inadequacies of an aging, non-professional, corrupt, non-imaginative and non-effective public service which keeps 
grinding and slowly but surely and unmindful of progress in a democratic dispensation (Abiola ibid.) the service must therefore undergo rebirth to complement the new vision and challenges of democracy and globalisation.

Therefore, the public service roles in democracy include, but not limited to the following: formulating policies that could empower the civil society economically and politically, encourage citizens to exhibit attitudes always push forward policy options that will allow for greater participation of the people in the state's political and economic processes, fashioning out and operationalizing the use of democratic means of resolving conflicts and erection of solid institutions for governance. Other means include exhibiting accountability and transparency in the work place, delivering of democracy dividends (in social amenities), upholding the integrity of the country, pushing for more equitable and fairer electoral order, supplying the manpower resources such that can meet the challenges of the $21^{\text {st }}$ century, beatifying meritocracy over mediocrity and meticulous implementation of policies.

There was no time in Nigeria's history when the Nigerian public service has been provided with the impetus to perform these tasks better than now. Public servants have been motivated to be more productive while government's reform measures in the area of monetisation of fringe benefits, pension reform, professionalisation and adjustment of retirement age are aimed at increasing the service's productivity. However, one must be careful that the productivity is primarily viewed in utilitarian terms. That is, its impact on the peoples quality of life.

Ever since the advent of the present democratic epoch, public officials have come to view their roles as not limited to formulating policies alone but that it includes formulating and implementing programmes in consultation with the civil society so as to continue upholding and protecting those ideals represented and safeguarded in a democracy. The innovative idea that this change in orientation produced is for example, the Offices of the Public Defender (OPD) in different states of the federation, aimed at increasing the access to justice in Nigeria.

Also, the public service has been of tremendous help in the government's privatisation and liberalisation programme. The private sector is the most promising foci of economic growth in a liberal democracy, such as ours. Hence, public officials have helped in nurturing a private sector that is vigorous and vibrant, bold and less parasitic on the people in the production process in order to facilitate sustainable development. This position is relevant to the extent that issues of economic and political prosperity cannot be separated form the achievement of democratic sustenance.

However, a critical view of the Nigerian public service reveals deep-seated contradictions capable of hampering the roles of the service in consolidating democracy. Although political institutions serve as important means of sustaining and re-enforcing democratic principles and values in the society, the question of individual rights is both social and political dimensions of human activity will definitely lead us to accept the fact that the institutions function ideally to safeguard the interests of the individual. Despite the modest achievement of the government in the creation of the OPD, the government and its policy formulators is haunted by its inability to institutionalise democracy because of the undermining of the people. This is reflected in several anti-people policies enthusiastically supported by bureaucrats e.g. the hike in fuel price and withdrawal of subsidy on petrol, the use of the armed forces to apply indictive attacks on innocent people, massive rigging of the 2003 general elections, etc. All these had the civil servants as active accomplices.

Furthermore, the public servants have acted more against the sustenance of democracy than it has acted in its support largely because of the penchant of the service for corruption. Rather than abate, bureaucratic corruption has become elevated to the level of preventing the people from benefiting from the dividends of democracy. The multifarious manifestation of bureaucratic corruption include the inflation of government contracts in return for kick backs, fraud and falsification of accounts in the public services, examination malpractice in our educational institutions, taking of bribes and perversion of justice etc. A House of Representative Committee on public account recently indicted government offices of acute degree of corruption (Vanguard, July 12, 2004: 1). All of these contributed tremendously to the failure of the public service contributing to democracy.

Finally, the level and quantity of manpower resources available to the public service is to say 
the least outdated and irrelevant to the challenges of the $21^{\text {st }}$ century. Most sensitive government works are now executed by consultants, many of whom has profit and not quality of human life as their motive. The result of this is that most often than not, government's projects are not done with the need of the people at heart while valuable resources are either pilfered or wasted. President Obasanjo himself painted a gory picture when he asked a select set of civil servants the reason why he continued to pay 23,000 workers in the ministry of works when most of the jobs are executed by consultants? The engagement of contract staff most of whom are defective in civil service procedures in sensitive positions has resulted in policy crises. Therefore, the public service has performed its expected roles in democratic consolidation mandate in breach than in observance.

\section{CONCLUSION}

The elected public officials are the major obstacles to efficiency and effectiveness of the public service. Most often, they make radical changes in orientation such that will facilitate development in the public service to fail. In this connection, they should be made to show genuiness of purpose to a more pro-active public service. Secondly, the present tight-hold of the government on the public administration process should be loosened. Motivation of officials is also essential. The government reform programme should be restructured in order to allow for a more systematic and result oriented application. It is however believed that stability in the political realm will ultimately engender stability and continuity of policy making and execution. Nevertheless, it has to be re-iterated that the public service is the institutional machinery of the executive arm of government. It is charged with the responsibility to analyse and transform government policies and intentions into practical realities (Ipinlaye, 2001: 130). Therefore, the success of the government itself depends on the bureaucrats. And finally, it has to be meaningfully enhanced in a stable and developing democracy.

\section{REFERENCES}

Abiola, Doyin 2004. "Senate's Face-off with El-Rufai:
Beyond Insult and Apology." Sunday Punch September 12

Adebayo, A. 1982. Principles and Practice of Public Administration in Nigeria. Ibadan: Spectrum

Agagu, A 1997. "Public Administration," in D. Kolawole (ed.) Readings in Political Science. Ibadan: Dekaal.

Aiyede, Remi. 2003. "Public Service Ethics in Nigeria' Local Government System", in Onu Godwin (ed.), Corruption and Sustainable Development: The Third World Perspectives. Onitsha, Anambra State: Bookpoint Ltd.

Ajayi, K. 2001. "Military Regimes and Nigerian Public Administration", in F. Omotoso (ed.), Contemporary Issues in Public Administration. Lagos: Bolabay Publications.

Ayo, B. 1998. "A Review of the Performance of the Nigerian Public Bureaucracy", in D. Kolawole (ed.), Issues in Nigerian Government and Politics. Ibadan: Dekaal.

Ayodele, B. 2004. "Ethno-Nationalistic Militarism and the Quest for Democratic Security in Post-Military Nigeria", in K. Ajayi and B. Ayodele (eds.), Perspectives on Democracy and Development in Post-Military Nigeria. Ibadan: Julius and Julius Associates.

Diamond, L., J. Linz, S. M. Lipset (Eds.). 1988. Democracy in Developing Countries. Boulder: Tynne Riveriea

Ejifor Pita. 2003. "Welcome Address by Chairman Conference Local Organising Committee," in Onu Godwin (ed.), Corruption and Sustainable Development: The Third World Perspectives. Onitsha, Anambra State: Bookpoint Ltd.

Enemuo, C 1999. "Democracy, Human Rights and The Rule of Law", in C. Enemuo and R. Anifowose (eds.), Elements of Politics. Lagos: Malthouse.

IDEA. 2001. Democracy in Nigeria: Continuing Dialogue(s) for Nation Building. Nigeria/Sweden: IDEA.

Ipinlaye, O. 2001. "The Nigerian Civil Service: An Insider's View", in F. Omotoso (ed.), Contemporary Issues in Public Administration. Lagos: Bolabay.

Kolawole, Dipo. 1998. "Colonial and Military Rules in Nigeria: A Symmetrical Relationship", in D. Kolawole (ed.), Issues in Nigeria Government and Politics. Ibadan: Dekaal Publishers.

Lukman, R. 1971. The Nigerian Military: A Sociological Analysis. Cambridge: Cambridge University Press.

Makinde, M. 2003. "A Philosophical Approach to the Problem of Ethics and Accountability in the Nigeria Public service", in E. O. Ezeani (ed.), Public Accountability in Nigeria: Perspectives and Issues. Enugu: Academic Publishing Company.

Mimiko, N. 1999. "Enhancing Democratic Consolidation in a Presidential System of Government", in N. Mimiko and D. Kolawole (eds.), Democracy and Public Administration in Nigeria. Akure: ABM.

Nnoli, D. 2000. "Public Administration" in R. Mukantala (ed.) African Public Administration: A Reader. Harare: AAPS.

Stone, D 1986. Planning and Administration in America. New York: Alfred Knopf.

The Guardian 2004. Service Monetisation Lagos. May 30 